\title{
Understanding: Swine Flu (H1N1) and COVID-19 (SARS-CoV-2) Pandemic
}

\author{
Dr. Vaishnavi Seetharaman", Dr. Rajvikram N, Dr. Bharath Marlecha R
}

Department of Orthodontics and Dentofacial Orthopaedics, Thai Moogambigai Dental College and Hospital, Dr. M.G.R Educational \& Research Institute, Golden George Nagar, Mogappair, Chennai 600107, Tamil Nadu, India

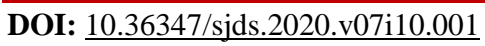

| Received: 22.09.2020 | Accepted: 30.09.2020 | Published: 03.09.2020

*Corresponding author: Dr. Vaishnavi Seetharaman

Abstract

Review Article

The entire planet is suffering from the current infection- COVID-19 and it has not only caused a depression in economy but had put every individual at a risk of catching the virus, especially the medical and dental health professionals who are in direct contact with the patients. As on 22 September, 2020 there are 34.1 million cases recorded for COVID-19, of which 21.5 million people recovered from the infection and sadly, 9.66 lakhs population died of COVID-19 infection. This does not make us forget the 2009 Swine flu pandemic that had infected 60 million population world-wide. The H1N1 virus was a new swine flu virus that had genetic material of swine, bird and human influenza virus in combination due to reassortment whereas SARS-CoV-2 is very similar to the SARS-CoV that happened in 2002-2003, indicating that a new person-to-person transmission of infectious agent (coronavirus) had caused the outbreak of the COVID-19 pandemic. In India, day by day the graph of COVID-19 infection is rising. So, it is important to take into consideration about both the pandemics as it may prove to be a deadly one.

Keywords: H1N1, Swine flu, COVID-19, Pandemic, Transmission.

Copyright @ 2020: This is an open-access article distributed under the terms of the Creative Commons Attribution license which permits unrestricted use, distribution, and reproduction in any medium for non-commercial use (NonCommercial, or CC-BY-NC) provided the original author and source are credited.

\section{H1N1 INFLUENZA (Swine Flu)}

\section{INTRODUCTION}

In 1918, world's deadliest pandemic- Spanish Flu infected around 500 million population with a sacrifice of 50 to 100 million people around the globe. The virus causing this havoc was the H1N1 Influenza virus. In 2009, a new strain of this virus emerged which was called H1N1 swine flu. This virus was a sub-type of Influenza A virus.

However, the 2009 H1N1 virus was not a zoonotic virus since it had transmitted from person to person and not from pigs to humans. This virus caused similar symptoms seen in swine due to the reassortment of the viral RNA structure which granted human to human spread. Earlier the Swine Influenza Virus (SIV) was restricted to pigs and the transmission to human was not more than 3 people. In March/April 2009 the new strain H1N1 was first reported in California and Texas and then even in Mexico and other states and the World Health Organization (WHO) on June 11, 2009 labelled it as a pandemic [1].

\section{MICROBIOLOGY}

The H1N1 influenza virus belonged to the orthomyxovirus and produces virions of 80 to $100 \mathrm{~nm}$ in diameter with an RNA genome size of $13.5 \mathrm{~kb}$. The surface envelope proteins- Hemagglutinin type 1 (H1) and Neuraminidase type 1 (N1) are how the new H1N1 strain differentiated from other strains of Influenza virus [2].

\section{Mode of Transmission:}

The virus enters through the mucous membrane found in eyes, nose and mouth and bind strongly to the receptors called $\alpha 2-6$ which are found in the nose, throat and upper air-way. The human to human transmission occurs through direct/indirect contact, respiratory droplets and not by eating pork and pork products, hence the new strain is not a zoonotic swine flu since it is not transmitted from pigs to humans but from person to person [3].

\section{Incubation Period}

1 to 4 days, with average of 2 days in most individuals but in some people, it may be as long as 7 10 days [4].

\section{High-Risk Individuals}

People suffering from chronic diseases such as diabetes mellitus, asthma, heart diseases, neuromuscular disease, children $<5$ years and adults $>65$ years, immune-compromised patients such as in AIDS, Pregnant ladies, patients with chronic lung disease, 
renal disease and hepatic disease, Auto-immune diseases, cancer, obesity and chronic smokers [5].

\section{Signs and Symptoms}

The most common symptom reported by the infected people in the 2009 outbreak was vomiting and diarrhea. But there were other symptoms recorded such as fever, cough, congested eyes, myalgia, chills, sore throat, headache, sneezing, fatigue, loss of appetite, breathlessness. Most common cause of death was reported to be due to respiratory failure. Other reasons of death included dehydration and hypotension (due to severe vomiting and diarrhea), sepsis, pneumonia, high fever [6].

\section{Prevention:}

Involves 3 check points [7]:

1. Prevention in Swine: This can be done by vaccinating the pigs in farm houses, proper facility management (disinfectants and temperature control), herd management (separating healthy pigs from diseased) and regular checks of the pigs by a veterinary doctor.

2. Prevention from swine to humans: Major risk of transmission from swine to humans is through very close contact with the pigs such as farmers, pork handlers and the veterinary doctors. So, it is highly recommended that a face mask that covers mouth and nose and disposable gloves to be used when handling the swine. The main method of prevention would be vaccinating the swine.

3. Prevention from human to human: The transmission occurs when an infected patient sneezes or coughs, through respiratory droplets or by touch of infected inanimate objects. This can be prevented by using face-mask when out in public. Avoid touching face, mouth and eyes using bare hands. Hand hygiene is very important. Hence, it is mandatory to use alcohol-based hand rubs or handwashing using soap \& water and using disposable tissues when a person sneezes and coughs. The public places, hospitals should be sanitized using diluted bleach solution. If anybody catches flulike symptoms then he/she should quarantine themselves for at least 10 days.

\section{Treatment:}

Can be delivered in 4 ways:

1. Passive Immunity through Vaccinations: In September 2009, the Food and Drug Administration (FDA) approved the new swine flu vaccine after thorough clinical trials and the National Institute of Health (NIH) added that the vaccine can create sufficient antibodies within 10 days of administering a single dose. There are 2 brands of vaccination availablePandemrix (single dose) and Celvapan (two doses, 3 weeks apart). According to Centers for Disease Control and Prevention (CDC), all pregnant ladies are administered with the vaccines to prevent swine flu and further severe complications to the mother and foetus. Contraindications: people of previous severe allergic reactions to vaccine or component of the vaccine, moderately to severely ill patients [8].

2. Anti-viral therapy: Two drugs which are available on prescription are- Oseltamivir (Tamiflu) and Zanamivir (Relenza) which are neuraminidase inhibitors. It has been demonstrated that these 2 drugs are effective when administered within 2 days of onset of the disease by decreasing the viral load in the body but the latest one being recommended is the Peramivir injection [9].

3. Symptomatic treatment: For headache, bodypain and fever- Paracetamol or NSAIDS can be prescribed. Antihistaminic for nasal congestion and Intravenous (I.V) hydration in case of dehydration, Antibiotics for secondary infections, ventilation for respiratory problems.

4. Ayurvedic approach: Many doctors believe that Ayurveda can boost the immunity in a person. Since the virus affects the immunity of a person, it is essential to strengthen it. Though this approach cannot be quick in curing but it is definitely a win in the long run. Natural entities like Basil leaves, Garlic, Ginger, Aloe Vera, Alma (Gooseberries), Camphor and Eucalyptus oil have proven to boost the immunity of a person [10].

\section{COVID-19 (Coronavirus Disease) INTRODUCTION}

Currently the entire globe is suffering from the COVID-19, which has become over time a household name. The first cases of the COVID-19 were reported in the beginning of December 2019 from the Wuhan City in China. Back then, when the causative organism was unknown, the cases were classified as 'Pneumonia of unknown etiology'. Upon investigation by the China Public health officials it was concluded that the new virus belongs to the coronavirus family. On January 30, 2020, the WHO in a meeting declared the outbreak to be a pandemic and was a Public Health Emergency of International Concern (PHEIC). Later on, February 11, 2020, the WHO termed the disease COVID-19 which is the acronym of 'coronavirus disease 2019'. At the initial phase of the spread, the new virus was called novel coronavirus 2019 (2019-nCoV) but later, International Committee on Taxonomy of Viruses (ICTV) termed it as SARS-CoV-2 as it was very similar to SARS-CoV outbreak 2002 [11].

\section{MICROBIOLOGY}

The coronavirus belongs to the Coronaviridae family and the order Nidovirales comprising a large, 
single, a positive sense RNA virus with an envelope ranging from $60 \mathrm{~nm}$ to $140 \mathrm{~nm}$ with spike like projections on its capsid giving it a crown like appearance and hence the name corona. 4 sub-types of coronavirus have been recorded: $\alpha-\mathrm{CoV} \& \beta-\mathrm{CoV}$ infect the humans and mammals whereas $\gamma-\mathrm{CoV} \& \delta-\mathrm{CoV}$ mainly infecting the birds. Sequence comparison of SARS-CoV-2 were found similar to the sequence in Bat CoV and Pangolin CoV [12-13].

\section{Mode of Transmission}

Like most of the viruses, coronavirus can be transmitted from person to person either directly by inhaling the droplets released by the infected person through cough/talk/sneeze or indirectly when an individual touches infected inanimate object. The virus enters the mucous membrane of the eyes, nose and mouth and bind to the ACE2 receptors found abundantly in the respiratory tract and also to the cells of salivary gland duct epithelium. The virus has also been reported to be found in the stool specimens on day 7 of the patient's illness suggesting the fecal-oral transmission route too. Recently, many scientists reported the WHO that it is an air-borne infection and necessary precautions had to be changed to curb it. Indefinitely, it was proved later that COVID-19 can be transmitted in closed indoors through air currents carrying the viral particles. The natural/primary host of 2019-nCoV was found to be Rhinolophus affinis (bat) and Pangolins being an intermediate host though there are many intermediate hosts between the bat and human [14].

\section{Incubation period:}

It varies from 2 to 14 days. It has been reported that even after 24 days, individuals spread the virus without any symptoms, categorizing them as asymptomatic [15].

\section{High-Risk Individuals}

It is more prone to infect people who are diabetic, $>60$ years old, have health conditions like lung or heart diseases, previous history of tuberculosis and pneumonia, asthmatic patients, immune-compromised patients, cancer patients, metabolically weak patients, smokers, pregnancy and obesity. Surprisingly, males were affected more than females [16].

\section{Signs and Symptoms}

Cases have been recorded where patients infected with coronavirus have no symptoms at all (asymptomatic) while fever, dry cough, sore throat and tiredness have been the most common among the symptoms reported. A few reported nasal congestions, headache, diarrhea, loss of taste or smell, rashes on skin and discoloration of toes [17]. Not all infected patients require hospitalization. About $80 \%$ patients recovered from the disease at home with proper self-isolation and quarantine in adjunct to medications prescribed by the physician.

\section{Prevention}

The most important precautionary methods to prevent the spread of the disease are as follows [18-20]:

1. Social distancing of at least 1 meter or 6 feet or 2 arms' length from others.

2. Frequent hand hygiene maintenance using soap and water for 30 seconds or alcoholbased hand sanitizers containing at least $60 \%$ alcohol for 20 seconds.

3. Avoid touching mouth, nose and eyes with bare hands.

4. Mandatory use of masks when out in public or gatherings.

5. When coughing, cover it with bend of elbow or a tissue and immediately dispose the same and wash hands immediately.

6. Monitor your health daily: Any symptoms of fever, cough or difficulty in breathing, report to the nearest physician immediately to rule of the worst.

7. Cleaning and disinfecting the work place, toilets, sinks often with sodium-hypochlorite, Phenolic compounds, hydrogen peroxide solution, Quaternary ammonium compounds, Dodecyl benzenesulfonic Acid (Environmental Protection Agency (EPA) registered disinfectants)

\section{Treatment:}

There is no specific anti-viral treatment or vaccination against COVID-19.

1. The treatment is purely symptomatic and oxygen therapy is the line of choice for respiratory impairment.

2. Mechanical ventilation may be necessary in most severe forms of the disease where patient is suffering from acute respiratory failure.

3. Other therapies include:

i. I.V Corticosteroids (Dexamethasone reduces deaths by one-third among critically-ill patients)

ii. Immunomodulatory drugs (Chloroquine, $500 \mathrm{mg}$ every 12 hours and hydroxychloroquine, $200 \mathrm{mg}$ every 12 hours). Both the drugs decrease the viral load in the infected body [21].

iii. Antiviral agents (preclinical studies suggest Remdesivir is effective both as prophylaxis and therapy of $\mathrm{CoV}$ infections). Yet, further research is being performed for the clinical trials before release in the market [22].

iv. Serotherapy (Antibodies are taken from the cured patients. According to the calculation, the amount of antibody dose required to cure one patient equals to the removal of antibodies from 3 recovered patients) [23]. Yet, further research is ongoing to prove its efficiency. 
v. Ayurvedic approach (Garlic, Ginger, Pepper are three natural anti-viral agents that combat viral infects), though this approach would require a lot of time to cure the patient [24].

\section{The Vaccine}

A vigorous scientific research is going on to develop COVID-19/SARS-CoV-2 Vaccine. There are currently more than 100 candidate vaccines in development throughout the globe, of which 8-10 are under clinical investigation. Due to the severe side effects seen in one of the volunteers' administered with the candidate vaccine at the Oxford University (OxfordAstraZeneca COVID-19 vaccine), the Phase 3 clinical trial was put on temporary halt to investigate the cause of the adverse reaction for the future public safety [25].

\section{Dental Considerations in Curbing the Spread of the Infection}

The protocols in dental clinics/hospitals, during both the pandemics are found to be very similar since the mode of transmission is the same. The main role of a dentist would be to stop the spread of the infection by identifying the patients with symptoms and assisting them to the physician for proper treatment. Necessary Personal Protective Equipment (PPE) should be worn by all the staffs and non-staffs. Proper waste disposal and fumigation should be performed after each patients' treatment and patient travel history is very important and at the same time recording the vitals of the patient is mandatory [26, 27]. It is advised by the WHO and CDC to handle only emergency cases and defer those that are non-emergent, that is, which are not posing a risk to the life of a patient.

\section{CONCLUSION}

From the 8 pandemics in the past, starting from the 1919 Spanish Flu, 1957 Asian Flu, 1968 Hong Kong Flu, 1980 HIV/AIDS, 2002 SARS-CoV, 2009 Swine Flu, 2012 MERS and 2014 Ebola virus outbreak. Presently, we are combating the $9^{\text {th }}$ pandemic of the history COVID-19. Thus, it is very important to understand from the past and present that public health must be prioritized in every nation and an individual must start boosting immunity by consuming healthy food.

\section{REFERENCES}

1. Parmar S, Shah N, Kasarwala M, Virpura M, Prajapati DD. A review on swine flu. J Pharm Sci Bioscientific Res. 2011;1(1):11-7.

2. Jilani TN, Jamil RT, Siddiqui AH. H1N1 influenza (swine flu). StatPearls [Internet]. 2020 Jun 29.

3. Wiwanitkit V. HIV and Swine Flu: A Short Summary. Kulak Burun Bogaz Ihtis Derg. 2009;19(2):57-61.

4. Kothalawala H, Toussaint MJ, Gruys E. An overview of swine influenza. Veterinary quarterly. 2006 Jun 1;28(2):45-53.
5. Ramirez A, Capuano AW, Wellman DA, Lesher KA, Setterquist SF, Gray GC. Preventing zoonotic influenza virus infection. Emerging infectious diseases. 2006 Jun;12(6):997.

6. Myers KP, Olsen CW, Gray GC. Cases of swine influenza in humans: a review of the literature. Clin. Infect. Dis. 2007 Apr 15;44(8):1084-8.

7. Rewar S, Mirdha D, Rewar P. Treatment and prevention of pandemic H1N1 influenza. Annals of global health. 2015 Sep 1;81(5):645-53.

8. Saxena RK, Tripathi P, Rawat G. Pandemism of swine flu and its prospective drug therapy. European journal of clinical microbiology \& infectious diseases. 2012 Dec 1;31(12):3265-79.

9. Wiwanitkit V. Antiviral drug treatment for emerging swine flu. La Clinica Terapeutica. 2009 May 1;160(3):243-5.

10. Shah A, Krishnamurthy R. Swine flu and its herbal remedies. Int J Eng Sci. 2013;2:68-78.

11. Singhal T. A review of coronavirus disease-2019 (COVID-19). The Indian Journal of Pediatrics. 2020 Mar 13:1-6.

12. Sohrabi C, Alsafi Z, O’Neill N, Khan M, Kerwan A, Al-Jabir A, Iosifidis C, Agha R. World Health Organization declares global emergency: A review of the 2019 novel coronavirus (COVID-19). International Journal of Surgery. 2020 Feb 26.

13. Rothan HA, Byrareddy SN. The epidemiology and pathogenesis of coronavirus disease (COVID-19) outbreak. Journal of autoimmunity. 2020 Feb 26:102433.

14. Peng X, Xu X, Li Y, Cheng L, Zhou X, Ren B. Transmission routes of 2019-nCoV and controls in dental practice. International Journal of Oral Science. 2020 Mar 3;12(1):1-6.

15. McAloon C, Collins Á, Hunt K, Barber A, Byrne AW, Butler F, Casey M, Griffin J, Lane E, McEvoy D, Wall P. Incubation period of COVID19: a rapid systematic review and meta-analysis of observational research. BMJ open. 2020 Aug 1;10(8):e039652.

16. Applegate WB, Ouslander JG. COVID- 19 presents high risk to older persons. Journal of the American Geriatrics Society. 2020 Apr;68(4):681.

17. Cascella M, Rajnik M, Cuomo A, Dulebohn SC, Di Napoli R. Features, evaluation and treatment coronavirus (COVID-19). InStatpearls [internet] 2020 Mar 8. StatPearls Publishing.

18. Watkins J. Preventing a covid-19 pandemic.

19. World Health Organization. Coronavirus disease 2019 (COVID-19): situation report, 72.

20. Greenhalgh T, Schmid MB, Czypionka T, Bassler $\mathrm{D}$, Gruer L. Face masks for the public during the covid-19 crisis. Bmj. 2020 Apr 9;369.

21. Cortegiani A, Ingoglia G, Ippolito M, Giarratano A, Einav S. A systematic review on the efficacy and safety of chloroquine for the treatment of COVID-19. Journal of critical care. 2020 Mar 10. 
22. Yavuz S, Ünal S. Antiviral treatment of COVID19. Turkish Journal of Medical Sciences. 2020 Apr 21;50(SI-1):611-9.

23. Sethi A, Bach H. Evaluation of current therapies for COVID-19 treatment. Microorganisms. 2020 Aug; 8(8):1097.

24. Girija PL, Sivan N. Ayurvedic treatment of COVID-19/SARS-CoV-2: A case report. Journal of Ayurveda and Integrative Medicine. 2020 Jun 19.

25. [Internet

source] https://www.nytimes.com/2020/09/08/health/coron avirus-astrazeneca-vaccine-safety.html
26. Pitak-Arnnop P, Schubert S, Dhanuthai K, Sappayatosok K, Bauer U, Ngamwannagul P, Liebert UG, Hemprich A. Swine-origin H1N1 influenza A virus and dental practice: a critical review. Clinical oral investigations. 2010 Feb $1 ; 14(1): 11-7$.

27. Ather A, Patel B, Ruparel NB, Diogenes A, Hargreaves KM. Coronavirus disease 19 (COVID19): implications for clinical dental care. Journal of endodontics. 2020 Apr 6. 